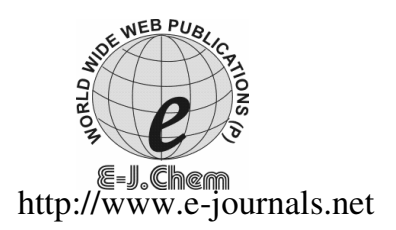

ISSN: 0973-4945; CODEN ECJHAO

E-Journal of Chemistry

2011, 8(4), 1925-1929

\title{
Preparation and Characterization of Nanocrystalline Hard Chromium Coatings Using Eco-Friendly Trivalent Chromium Bath
}

\author{
V.S. PROTSENKO ${ }^{\star}$, V.O. GORDIIENKO ${ }^{\S}$, F.I. DANILOV ${ }^{\S}$ and S.C. KWON \\ ${ }^{\S}$ Department of Physical Chemistry \\ Ukrainian State University of Chemical Technology \\ Gagarin Av. 8, Dnepropetrovsk, 49005, Ukraine \\ Surface Engineering Department \\ Korea Institute of Machinery and Materials \\ 66 Sangnam-dong, Changwon, Gyeongnam 641-010, Republic of Korea \\ vprotsenko@smtp.ru
}

Received 29 January 2011; Accepted 12 April 2011

\begin{abstract}
A new aqueous sulfate trivalent chromium bath is described. The chromium bath contains formic acid and carbamide as complexing agents. Chromium was deposited at a temperature of $30 \div 40{ }^{\circ} \mathrm{C}$ and a cathode current density of $10 \div 25 \mathrm{~A} \mathrm{dm}^{-2}$. The bath allows obtaining thick (up to several hundred micrometers) hard chromium coatings with nanocrystalline structure. The electrodeposition rate reaches $0.8 \div 0.9 \mu \mathrm{m} \mathrm{min}^{-1}$.
\end{abstract}

Keywords: Hard chromium electrodeposition, Trivalent chromium bath, Nanocrystalline

\section{Introduction}

Hard chromium electrodeposition is extensively used in modern industry because of extraordinary properties of chromium deposits. Commonly, chromium coatings are deposited from hazardous hexavalent chromium baths. In view of a very high toxicity of $\mathrm{Cr}(\mathrm{VI})$ compounds, development of chromium electroplating processes on the base of $\mathrm{Cr}$ (III) salts is a very important task of modern electroplating.

Many investigations dealing with development of effective trivalent chromium baths have been carried out ${ }^{1-12}$. Unfortunately, the proposed baths are not always sufficiently stable. Additionally, it is rather difficult to deposit thick high-quality chromium layers from trivalent chromium baths.

Recently, trivalent Cr-baths containing simultaneously formic acid (or formates) and carbamide (urea) were proposed ${ }^{13-16}$. These baths seem to allow obtaining thick chromium coatings with a rather large current efficiency. 
Nevertheless, in is not clear whether these baths allow performing a stable long-time electrolysis. The effect of electrolysis conditions on the properties of $\mathrm{Cr}$-coatings as well as on the current efficiency of chromium deposition and deposition rate is practically unexplored.

The aim of this work was to investigate more comprehensively eco-friendly chromium electroplating process from the trivalent sulfate chromium bath containing carbamide and formic acid.

\section{Experimental}

Chromium electrodeposition was performed galvanostatically in a usual glass cell. During the electroplating, the electrolyte was maintained with an isothermal condition. Chromium was deposited on a disc electrode of copper foil fixed in a plastic holder. Prior to each experiment, the surface of copper foil was treated with magnesium oxide and then rinsed with hydrochloric acid solution and distillate water.

The electrolysis was carried out either with titanium-manganese dioxide anodes (TMDA) $)^{17,18}$ or with anodes made from platinized titanium. On these anodes, the electrooxidation of $\mathrm{Cr}$ (III) ions to $\mathrm{Cr}(\mathrm{VI})$ occurs with a rather small rate. Therefore, chromium electroplating was performed without separation of anode and cathode compartments.

The current efficiency was calculated by comparing the weight gain of the cathode placed in the chrome-plating bath with that of a copper coulometer connected in series. The morphology of deposits was investigated by scanning electron microscopy (EVO 40XVP). The samples used in SEM-study were electroplated on the electropolished $\mathrm{Cu}$-substrate, the thickness of deposits being about $20 \mu \mathrm{m}$. The hardness of chromium coatings was determined using a PMT-3 set-up at a load of $100 \mathrm{~g}$ and the coating thickness of about $20 \mu \mathrm{m}$.

\section{Results and Discussion}

Effect of bath composition and electrolysis conditions on the current efficiency and chromium deposition rate

In our preliminary experiments, we established the basic bath composition as well as the deposition conditions which allow obtaining high-quality thick chromium layers (Table 1). Formic acid and carbamide play role of complexing agents. Sodium sulfate, aluminium sulfate and boric acid are conducting salts and buffer agent, respectively. Sodium dodecyl sulfate is used as a surfactant.

Table 1. Basic trivalent chromium bath composition and operating conditions

\begin{tabular}{cc}
\hline Constituents of plating bath & Concentration, mol/L \\
\hline Chromium(III) sulfate salt & 1.0 (referred to the metal chromium content) \\
$\mathrm{HCOOH}$ & 0.5 \\
$\mathrm{CO}\left(\mathrm{NH}_{2}\right)_{2}$ & 0.5 \\
$\mathrm{Al}_{2}\left(\mathrm{SO}_{4}\right)_{3} \cdot 18 \mathrm{H}_{2} \mathrm{O}$ & 0.15 \\
$\mathrm{Na}_{2} \mathrm{SO}_{4}$ & 0.3 \\
$\mathrm{H}_{3} \mathrm{BO}_{3}$ & 0.5 \\
Sodium dodecyl sulfate & $0.1 \mathrm{~g} \mathrm{~L}^{-1}$ \\
Operating conditions & 1.5 \\
pH & $30 \div 40{ }^{\circ} \mathrm{C}$ \\
Bath temperature & $10 \div 25 \mathrm{~A} / \mathrm{dm}^{2}$ \\
Cathodic current density &
\end{tabular}


The current efficiency and the chromium deposition rate were stated to depend appreciably on the value of $\mathrm{pH}$. An increase in $\mathrm{pH}$ leads to an increase in values of current efficiency and rate of chromium electroplating. However, at high $\mathrm{pH}$, the deposits are dark and they crack intensively along the edges of the cathode sample. Therefore, we think that the optimal value of $\mathrm{pH}$ is about 1.5.

It should be stressed that the current efficiency of common chromium baths does not exceed $10-20 \%{ }^{19}$. As can be seen, the current efficiency of chromium electroplating from the proposed trivalent chromium bath is sufficiently greater than in the case of ordinary hexavalent chromium baths.

The current efficiency of chromium deposition from the bath under study was shown to increase with an increase in the cathodic current density and a decrease in the bath temperature (Figure 1).

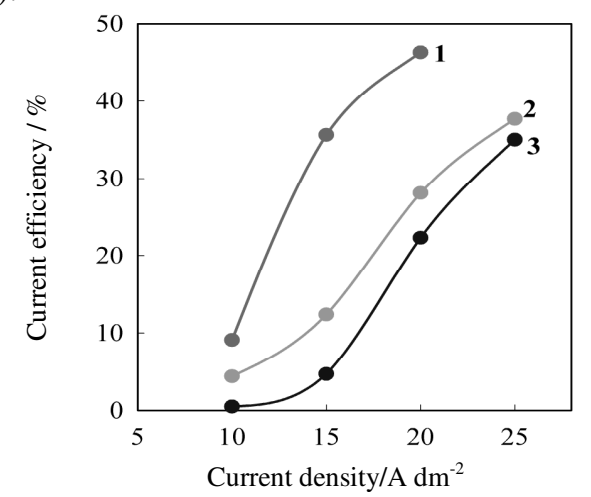

Figure 1. Dependences of current efficiency on current density at different bath temperatures: (1) $30{ }^{\circ} \mathrm{C},(2) 35^{\circ} \mathrm{C},(3) 40{ }^{\circ} \mathrm{C}$ basic bath composition; $\mathrm{pH} 1.5$

Decreasing the bath temperature results in deterioration of deposits surface appearance - they are not bright enough at the bath temperature of $30^{\circ} \mathrm{C}$. Hence, the optimal value of the bath temperature is about $35^{\circ} \mathrm{C}$.

If the value of cathodic current density of chromium deposition is more than $25 \mathrm{~A} \mathrm{dm}^{-2}$, the surface appearance of chromium deposits becomes poor. The surface of the deposits is rough and not bright at these values of current density. Thus, the most favorable current density is close to $15 \div 20 \mathrm{~A} \mathrm{dm}^{-2}$.

As was stated, the current efficiency does not virtually change with deposition time. Therefore, the electrodeposition rate is practically independent of the electrolysis time. This observation is highly important and favorable for practical use.

\section{Structure of deposits and surface morphology}

By means of the small-angle x-ray scattering (SAXS) method, we have stated that the coatings deposited from the trivalent chromium bath under study have a nanocrystalline structure; there are regions with atomic ordered arrangement in bulk material with the average size of $3 \div 5 \mathrm{~nm}$. We will investigate and describe this question more thoroughly in a separate communication.

Figure 2 is the surface morphology of the Cr-electrodeposits observed by scanning electron microscopy. As can be seen, the surface exhibits a great number of spheroids with different diameters. 


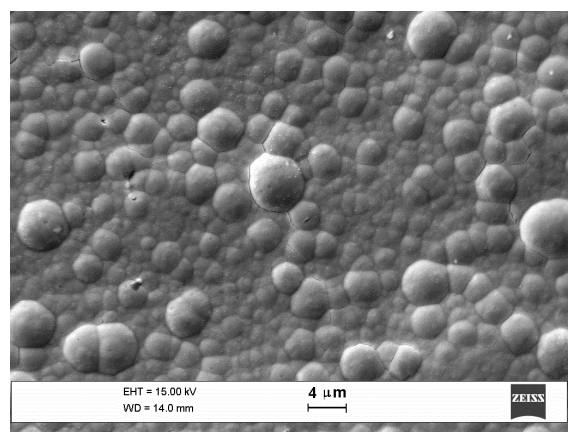

Figure 2. SEM images of Cr-coating obtained from the chromium bath with the basic composition thickness of deposits $20 \mu \mathrm{m}$ current density $20 \mathrm{~A} \mathrm{dm}^{-2}$; temperature $35^{\circ} \mathrm{C}$; $\mathrm{pH} 1.5$

\section{Hardness of deposits}

The influence of the current density as well as the bath temperature on the hardness of deposits is shown in Figure 3. The hardness of deposits proved to increase when current density increases from 15 to $25 \mathrm{~A} \mathrm{dm}^{-2}$. The hardness of coatings diminishes appreciably with an increase in the bath temperature. Let is note that the hardness of deposits under study possesses the values which are typical of the common chromium coatings deposited from hexavalent baths.

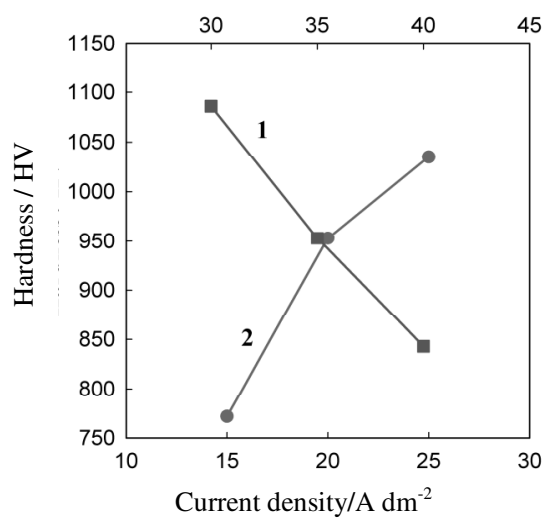

Figure 3. Dependences of chromium deposits hardness on bath temperature (1) and current density (2) basic bath composition (1) $\mathrm{pH} \mathrm{1.5,} \mathrm{current} \mathrm{density} 20 \mathrm{~A} \mathrm{dm}^{-2}$; (2) $\mathrm{pH} 1.5$, temperature $35^{\circ} \mathrm{C}$

\section{Conclusion}

Effect of the electrolysis conditions on the current efficiency, deposition rate, and hardness of deposits was studied using a sulfate trivalent chromium bath containing simultaneously both formic acid and carbamide as complexing agents.

The electroplating rate does not practically change during electrolysis time, the metal deposition rate being $0.7-0.9 \mu \mathrm{m} \mathrm{min}^{-1}$. An absence of hazardous halogen containing compounds is an essential advantage of the trivalent chromium bath proposed. Using titanium-manganese dioxide anodes or anodes made of platinized titanium permits performing chromium deposition without separation of anodic and cathodic compartments. 
The nanocrystalline thick coatings deposited from the bath under study are bright and smooth. The hardness of Cr-coatings does not differ substantially from that which is typical of deposits obtained from usual hexavalent chromium baths.

\section{References}

1 Smart D, Such T E and Wake S J, Trans Inst Met Finish., 1983, 61, 105.

2 Hong G, Siow K S, Zhiqiang G and Hsieh A K, Plat Surf Finish., 2001, 88, 69.

3 Song Y B and Chin D T, Electrochim Acta., 2002, 48(4), 349.

4 Kwon S C, Kim M, Park S U, Kim D Y, Kim D, Nam K S and Choi Y, Surf Coat Technol., 2004, 183(2-3), 151-156.

5 Danilov F I, Protsenko V S, Butyrina T E, Vasil'eva E A and Baskevich A S Prot. Met. 2006, 42, 560.

$6 \quad$ Li B S and Lin A, Key Eng Mater., 2008, 373-374, 200-203.

7 Saravanan G and Mohan S, J Appl Electrochem., 2010, 40, 1.

8 Edigaryan A A and Polukarov Yu M, Zashch Met., 1998, 34, 117.

9 Edigaryan A A and Polukarov Yu M, Zashch Met., 1999, 35(1), 5.

10 Mohan S, Vijayakumar J and Saravanan G, Surf Eng., 2009, 25(8), 570-576.

11 Protsenko V and Danilov F, Electrochim Acta, 2009, 54, 5666-5672.

12 Drela I, Szynkarczuk J and Kubicki J, J Appl Electrochem., 1989, 19, 933.

13 Kuznetsov V V, Vinokurov E G and Kudryavtsev V N, Russ J Electrochem., 2001, 37, 699 .

14 Survilene S, Nivinskiene O, Cesuniene A and Selskis A, J Appl Electrochem., 2006, 36, 649 .

15 Surviliene S, Jasulaitiene V, Nivinskiene O and Cesuniene A, Appl Surf Sci., 2007, 253(16), 6738-6743.

16 Danilov F I, Protsenko V S, Gordiienko V O, Kwon S C, Lee J Y and Kim M, Appl Surf Sci., 2011, 257, 8048

17 Danilov F I, Velichenko A B, Loboda S M and Kalinovskaya S E, Elektrokhimiya, 1987, 23, 988.

18 Danilov F I and Velichenko A B, Electrochim Acta, 1993, 38(2-3), 437-440.

19 Dennis J K and Such T E, Nickel and Chromium Plating; Butterworths: London, 1986. 


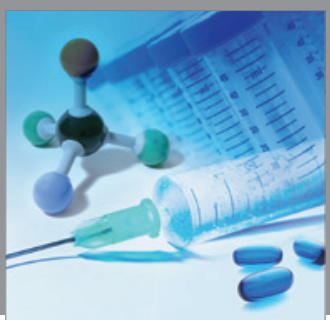

International Journal of

Medicinal Chemistry

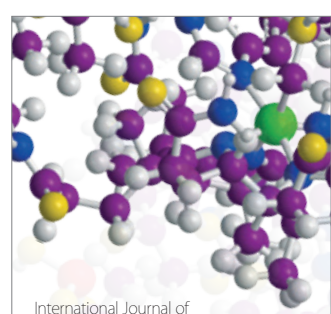

Carbohydrate Chemistry

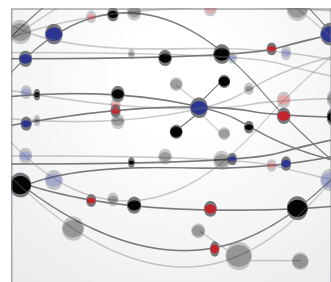

The Scientific World Journal
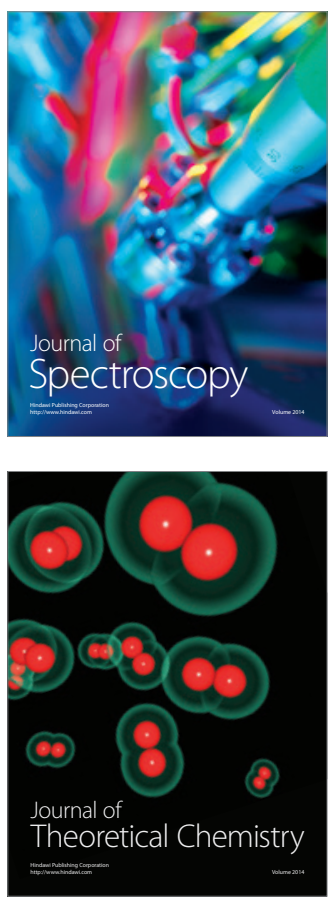
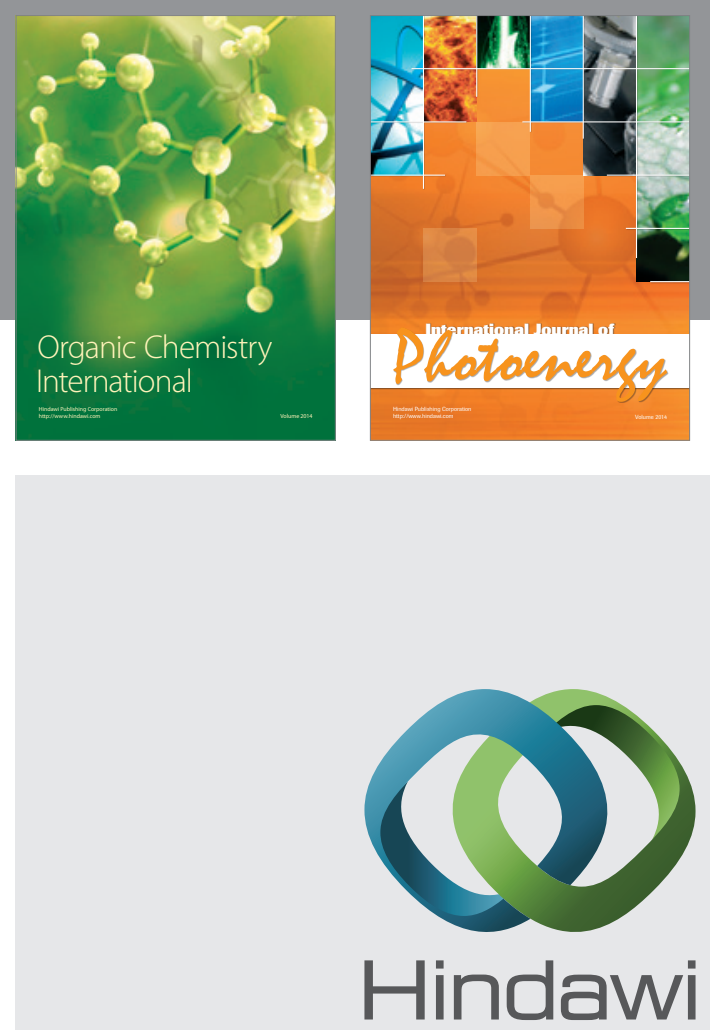

Submit your manuscripts at

http://www.hindawi.com
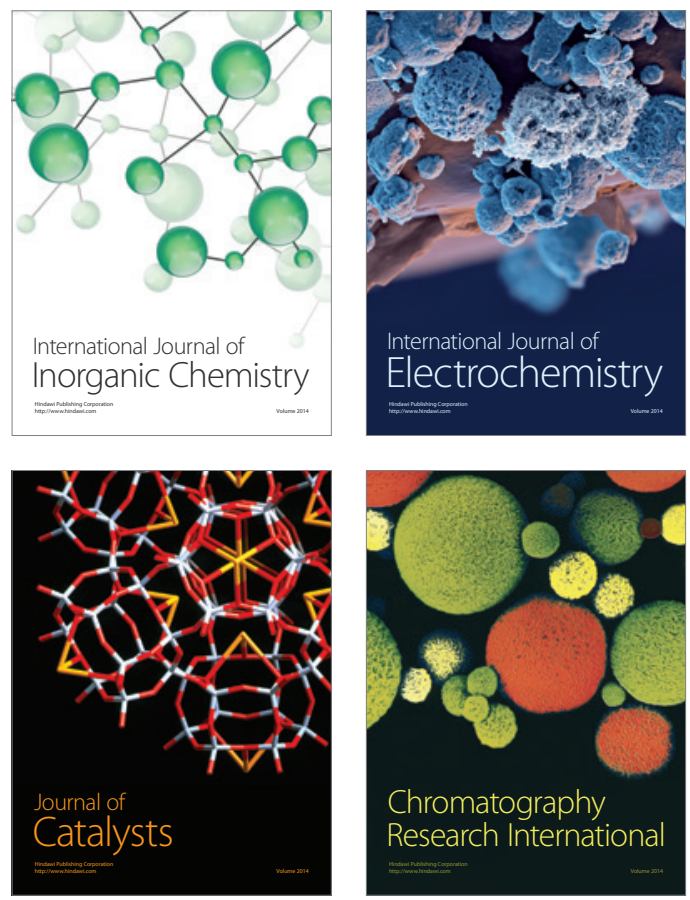
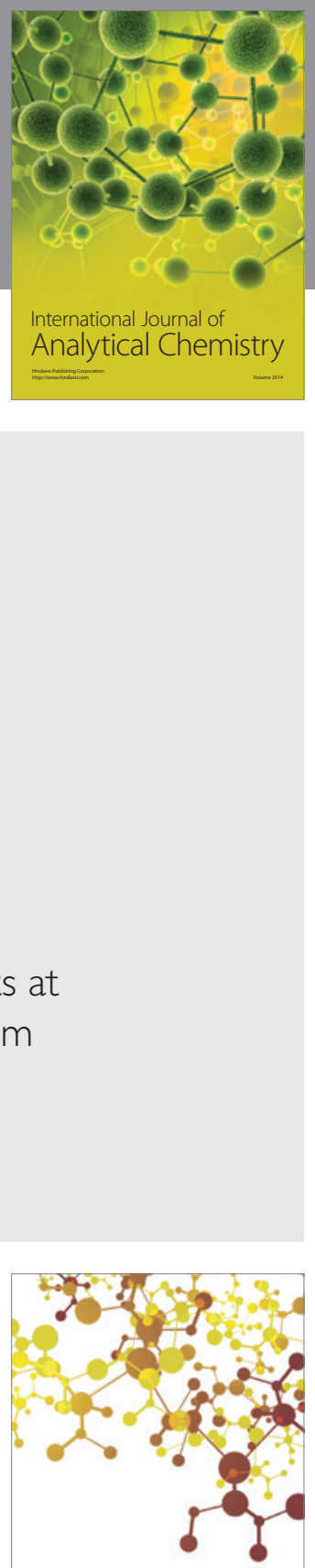

Journal of

Applied Chemistry
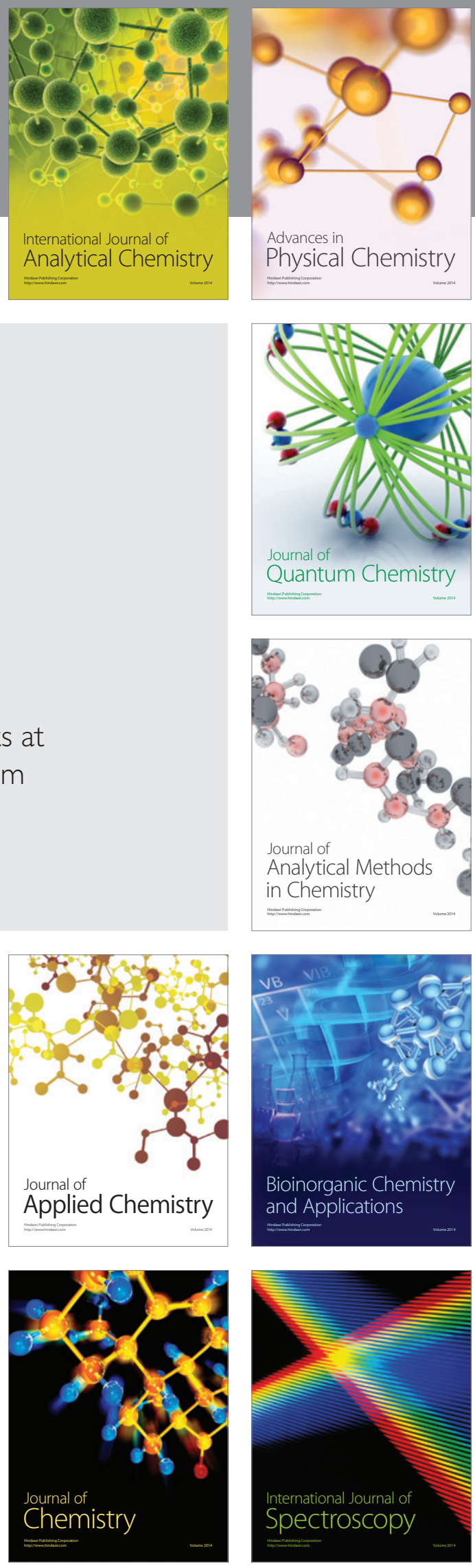